\title{
Chronic Kidney Failure: Knowledge of Kidney Disease, Perception of Causes and Symptomatology in Uyo, Nigeria
}

\author{
Effiong Ekong Akpan, Udeme E. Ekrikpo \\ University of Uyo, Uyo, Nigeria \\ Email: ffngakpan@yahoo.com, udekrikpo@yahoo.com
}

Received 17 August 2015; accepted 4 September 2015; published 7 September 2015

Copyright (C) 2015 by authors and Scientific Research Publishing Inc.

This work is licensed under the Creative Commons Attribution International License (CC BY). http://creativecommons.org/licenses/by/4.0/

(c) (i) Open Access

\section{Abstract}

Background: Chronic kidney disease (CKD) is now regarded as a global public health epidemic. Management of chronic kidney disease is often beyond the reach of some patients especially in resource-poor countries of sub-Saharan Africa where patients have to bear the funding. Many Nigerians do not know the functions of the kidney, the symptoms of kidney diseases and the causes of kidney failure. Aims: This study was designed to assess the awareness and knowledge of the kidney and kidney diseases among the people of Akwa Ibom State of Nigeria and their perception of the causes of kidney failure. Method: This was a cross-sectional survey of the Uyo residents in Akwa Ibom State for their knowledge, awareness and perception of CKD. A well structured but simple questionnaire was administered on all medically naïve participants by trained personnel. Data were analyzed using STATA 10, StataCorp, Texas, USA. Categorical data were presented as frequencies and percentages. A p-value of $<0.05$ was considered statistically significant. Results: A total of $\mathbf{5 0 0}$ questionnaires were distributed, but 410 were returned. There were 214 (52.2\%) females and 196 (47.8\%) males with an age range of 18 to 60 years and a mean age of $25.97 \pm 8.60$ years. About ninety five percent $(\mathbf{9 5 . 1 \% )}$ ) of respondents had heard about CKD with their major source of knowledge being from doctors $(29.4 \%)$ and media (28.9\%). Only $43.3 \%$ of respondents knew the correct location of the kidneys. With regards to the knowledge and perception of the causes of kidney failure and body swelling, (11\%) agreed that it was because of patient's wrongdoing, Hypertension (38.9\%), False oath taking (20.8\%), Witchcraft (12.7\%), Diabetes (46.9\%), Parent's wrongdoing (6.4\%), Sickle cell disease (47.3\%), Familial (19.8\%), Herbal medicine (27.9\%), Drug abuse $(38.9 \%)$ and Fake drugs $(\mathbf{4 2 . 1 \%})$. The well educated had better knowledge of hypertension and diabetes as the causes of kidney failure. In conclusion, knowledge of kidney disease is still poor among our populace and more education and public enlightenment is therefore needed.

\section{Keywords}

Awareness, Perception, Chronic Kidney Failure, Nigeria 


\section{Introduction}

Kidney disease is now regarded as a global public health epidemic. According to the Global Burden of Disease (GBD) 2010, CKD now ranks as the $9^{\text {th }}$ cause of death, $16^{\text {th }}$ cause of year of life lost from premature death, and $22^{\text {nd }}$ cause of year lived with disability and adjusted life year (DALYs) in the United States [1]. This picture may be worse in resource-poor countries like ours. Management of CKD is often beyond the reach of some patients especially in resource-poor countries of sub-Saharan Africa where patients and their relatives have to bear the funding [2]. Many Nigerians do not know the functions of the kidney, the symptoms of kidney disease and the causes of kidney failure [3]. Many people among the Efik, Ibibio and Annang ethnic groups of Cross River and Akwa Ibom states of Nigeria believe that some of the symptoms of kidney failure especially body swelling is due to evil spirit. It is either because of the patient's wrongdoing or the patient is a thief.

In some instances, the families of deceased patients have been known to conduct certain rituals to appease the local deity as well as mutilate the corpse before burial in-order to prevent other family members from coming down with similar ailments. Because of these beliefs and relatively cheaper cost of treatment by tradomedical practitioners is often first preferred. The few that seek medical treatment often present late in the hospital with a number of them presenting in either stage 4 or 5 CKD [4].

This study was designed to assess the awareness and knowledge of the kidney and Chronic Kidney Disease among the people of Akwa Ibom and their perception of the cause kidney failure.

\section{Methodology}

This was a cross-sectional survey of Uyo residents for the knowledge, awareness and perception of kidney disease. Uyo is the capital of Akwa Ibom State of Nigeria. The state is named after the great Qua-Iboe River. Being the state capital, it receives people from all the 31 local government areas of the state. Medically-naïve members of the population cutting across different types of occupation and all levels of education were recruited for the study. A convenience sampling of medically naïve respondents was performed. The medically-naïve respondents refers to those who had never worked in a hospital setting before, either as health service providers or health management and support staffs. A well-structured but simple questionnaire was administered on all participants by trained personnel. Both English and Ibibio languages were used. Ibibio language is well understood by the three major ethnic groups in Akwa Ibom State. Their knowledge of the location and functions of the kidneys were assessed. Their knowledge of symptoms of kidney failure as well as beliefs on the causes of kidney failure was also assessed.

\subsection{Data Handling}

Data was entered and analyzed using STATA 10, StataCorp, Texas, USA. Categorical data was presented as frequencies and percentages. Chi-square was employed in comparing the proportions of the various responses between individuals with less than a secondary school education and those with at least a secondary school education. A p-value of $<0.05$ was considered statistically significant.

\subsection{Exclusion Criteria}

All health personnel as well as medical and paramedical students were excluded from the study.

\section{Results}

A total of 500 questionnaires were distributed, but 410 were returned giving a response rate of $82 \%$. There were 214 (52.2\%) females and 196 (47.8\%) males with an age range of 18 to 60 years and a mean age of $25.97 \pm 8.60$ years. Only 352 respondents indicated their marital status of which 121 (34.4\%) were married while 231 (65.6\%) were single. $22.2 \%$ had no formal education while $1.0 \%, 27.07 \%, 49.8 \%$ had primary, secondary and post secondary education respectively. Majority of respondents were Christians $88.3 \%$ (Table 1).

We examined knowledge of kidney diseases, number of kidneys, location and functions. Out of 407 who responded to this question, 387 (95.1\%) had knowledge of kidney diseases. Of those who had knowledge 113 (29.4\%), 39 (10.2\%), 56 (14.6\%), 111 (28.9\%), 50 (13.0\%) and 15 (3.9\%) had their source of information from doctors, nurses, friends, media, relatives and school respectively. On the outcome of the patient they knew, 68 (24.03\%) said the patient had died while 215 (76.0\%) said the patient is still alive. On the location of the kidneys, 
surprisingly 211 (52.2\%) said the kidneys are located in the chest, 175 (43.3\%) and $1(0.3 \%)$ said the kidneys are located in the abdomen and head respectively. While 17 (4.20\%) had no idea. With regards to their knowledge of kidney functions, 384 (94.6\%) said yes to urine formation, 369 (90.4\%) to waste excretion, 287 (79.5\%) to calcium and phosphate regulation, and on the kidney's ability to aid blood production, 281 (70.1\%) said yes (Table 2).

Knowledge of the symptoms of kidney failure is as shown in Figure 1.

Knowledge and perception of causes of kidney failure and body swelling were as follows: Eleven (11\%) agreed that it is because of patient's wrongdoing while $53.8 \%$ and $35.2 \%$ disagreed and had no idea respectively; Hypertension; agree (38.9\%), disagree (35.5\%), no idea (27.6\%). False oath taking agree (20.9\%), disagree (36.2\%), no idea (43.0\%). Stole something; agree (9.3\%), disagree (56.2\%), no idea (34.5\%). Witchcraft; agree (12.7\%), disagree (54.8\%), no idea (32.5\%). Diabetes; agree (46.9\%), disagree (34.5\%), no idea (18.6\%). Parent's wrongdoing; agree (6.4\%), disagree (67.5\%), no idea (26.2\%). Sickle cell disease; agree (47.3\%), disagree (20.06\%), no idea (30.6\%). Familial; agree (19.8\%), disagree (44.0\%), no idea (36.2\%). Herbal medicine; agree (27.9\%), disagree (35.3\%), no idea (36.8\%). Drug abuse (38.9\%), disagree (27.9\%), no idea (33.3\%). Diarrhoea; agree (38.9\%), disagree (36.4\%), no idea (24.7\%). Blood loss; agree (42.8\%), disagree (31.3\%), no idea (25.9\%). Fake drugs; Agree (42.1\%), disagree (22.7\%), no idea (35.2\%) (Figure 2).

We analyzed the effect of educational status on perception of kidney failure. Surprisingly more of the well educated believed that kidney disease can be caused by the patient's wrongdoing $(p=0.03)$. More of the well educated also believed that hypertension $(p \leq 0.001)$ and diabetes $(p=0.002)$, familial causes $(p \leq 0.0001)$, diarrhoea $(\mathrm{p}=0.01)$ and fake drugs $(\mathrm{p}=0.01)$ are causes of kidney failure. While the less educated and no formally educated believed that it is as a result a curse placed on a thief following an act of stealing $(\mathrm{P} \leq 0.0001)$ is a more likely cause of kidney failure (Table 3).

African traditional methods were preferred for treatment of kidney failure among $11.3 \%$ of the less educated compared to $7.4 \%$ of the well educated $(p=0.14)$.

\section{Discussion}

The overall awareness of the kidney disease was good among the respondents as only about $5 \%$ did not hear about kidney disease. This may be because we study the urban dwellers with more educated respondents. It may also be attributed to the intensive enlightenment of the populace on kidney diseases. Same study was conducted by Okaka and Ojogwu [5] although mainly among undergraduate. Doctors topped the source of knowledge of kidney diseases with $29.4 \%$, followed by the media (28.9\%) while schools had the least (3.9\%) as shown in Table 2. A lot still needs to be done on health education especially in the schools, which may require a revision of their curriculum. Both health workers and the media need to do more in bringing information of kidney disease to the populace. Of those who knew a patient with kidney disease, $24 \%$ of them acknowledged that the patient died of kidney disease. This shows a high mortality rate associated with kidney disease among our patients [2] [6]. A greater percentage of the respondents did not know the location of the kidneys. Only $43.3 \%$ knew that the

Table 1. Socio-demographic characteristics of respondents.

\begin{tabular}{|c|c|c|c|}
\hline & Variables & Frequency & Percentage \% \\
\hline \multirow{2}{*}{ Sex } & Male & 214 & 52.2 \\
\hline & Female & 196 & 47.8 \\
\hline \multirow{2}{*}{ Marital status } & Married & 121 & 34.4 \\
\hline & Single & 231 & 65.6 \\
\hline \multirow{4}{*}{ Educational status } & No formal education & 91 & 22.2 \\
\hline & Primary education & 4 & 1.0 \\
\hline & Secondary education & 111 & 27.1 \\
\hline & Post secondary education & 204 & 49.8 \\
\hline \multirow{3}{*}{ Religion } & Christianity & 362 & 88.3 \\
\hline & Islam & 9 & 2.2 \\
\hline & Others & 39 & 9.5 \\
\hline
\end{tabular}


Table 2. Knowledge of kidney disease; number, location and functions of the kidneys.

\begin{tabular}{|c|c|c|c|}
\hline Variable & & Frequency & Percentage \% \\
\hline Knowledge of kidney disease & Yes & 387 & 95.1 \\
\hline \multirow{6}{*}{ Source of knowledge } & Doctors & 113 & 29.4 \\
\hline & Nurse & 39 & 10.2 \\
\hline & Friends & 56 & 14.6 \\
\hline & Media & 111 & 28.9 \\
\hline & Relatives & 50 & 13.0 \\
\hline & School & 15 & 3.9 \\
\hline Know patient with kidney disease & Yes & 283 & 69.0 \\
\hline \multirow{2}{*}{ Outcome of the patient } & Dead & 68 & 24.0 \\
\hline & Alive & 215 & 76.0 \\
\hline \multirow{4}{*}{ Location of kidneys } & No idea & 17 & 4.2 \\
\hline & Abdomen & 175 & 43.3 \\
\hline & Head & 1 & 0.3 \\
\hline & Chest & 211 & 52.2 \\
\hline \multirow{4}{*}{ No of kidneys } & No idea & 1 & 0.3 \\
\hline & One & 8 & 2.0 \\
\hline & Two & 382 & 97.2 \\
\hline & Three & 2 & 0.5 \\
\hline \multirow{4}{*}{ Functions of kidney } & Urine formation & 384 & 94.6 \\
\hline & Waste excretion & 369 & 90.4 \\
\hline & Calcium and phosphate regulation & 287 & 79.5 \\
\hline & Aid blood production & 281 & 70.1 \\
\hline
\end{tabular}

Table 3. Comparison of perception indices by educational status.

\begin{tabular}{cccc}
\hline Perception indices & Post secondary school education. N (\%) & Secondary school and below. N (\%) & p value \\
\hline Patient's wrongdoing & $24(21.8)$ & $21(13.6)$ & 0.03 \\
Hypertension & $104(51.2)$ & $55(26.7)$ & $<0.001$ \\
Took oath falsely & $41(20.2)$ & $44(21.4)$ & 0.77 \\
Stole something & $11(5.4)$ & $27(13.1)$ & $<0.0001$ \\
Witchcraft & $24(11.8)$ & $28(13.6)$ & 0.59 \\
Parent's wrongdoing & $11(5.4)$ & $15(7.3)$ & 0.44 \\
Diabetes mellitus & $114(56.2)$ & $78(37.9)$ & 0.002 \\
Sickle cell disease & $105(52.0)$ & $88(44.7)$ & 0.06 \\
Familial & $57(28.1)$ & $24(11.7)$ & $<0.0001$ \\
Herbal drugs & $55(27.1)$ & $59(28.9)$ & 0.70 \\
Drug abuse & $77(35.5)$ & $89(42.2)$ & 0.16 \\
Diarrhoea & $92(45.3)$ & $64(32.5)$ & 0.01 \\
Excessive blood loss & $96(47.3)$ & $79(38.4)$ & 0.07 \\
Fake drugs & $98(48.3)$ & $74(35.9)$ & 0.01 \\
\hline
\end{tabular}




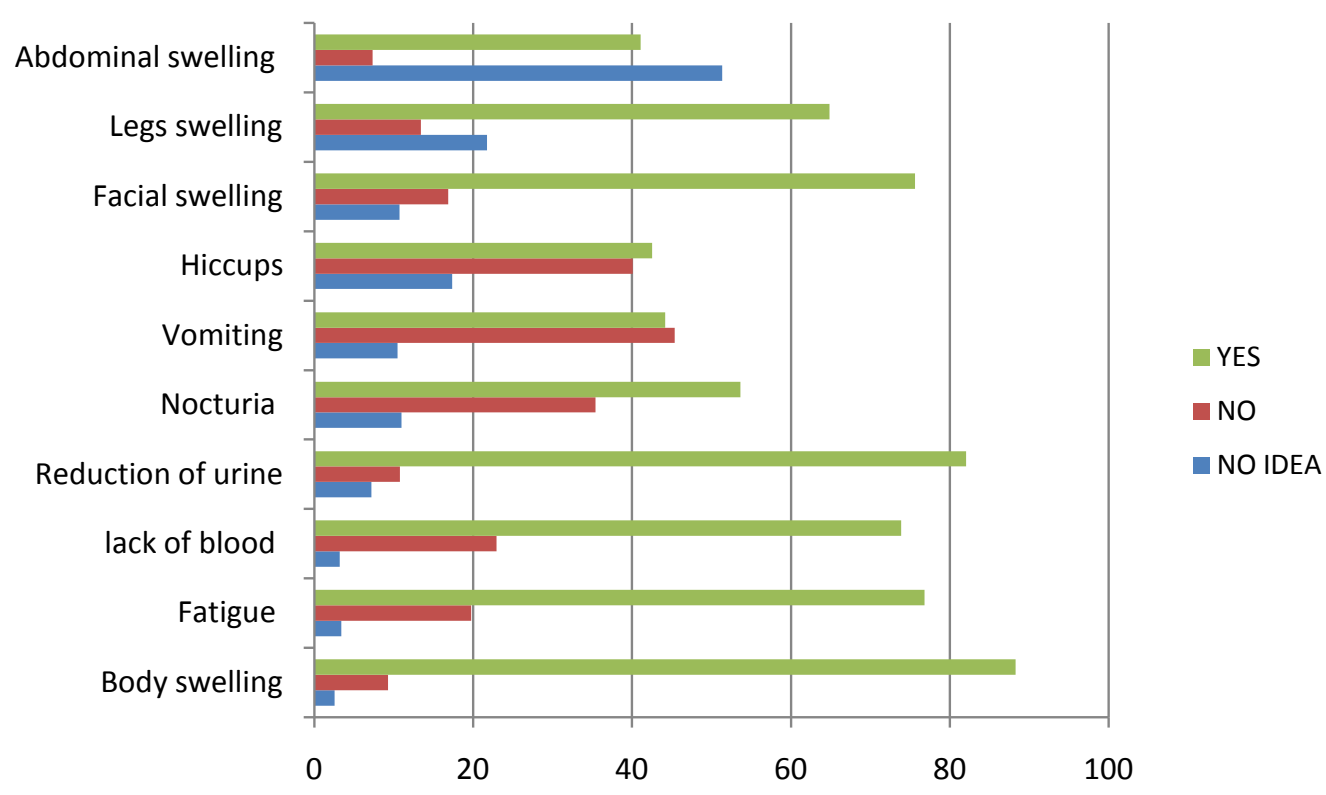

Figure 1. Histogram showing the knowledge of symptoms of kidney failure.

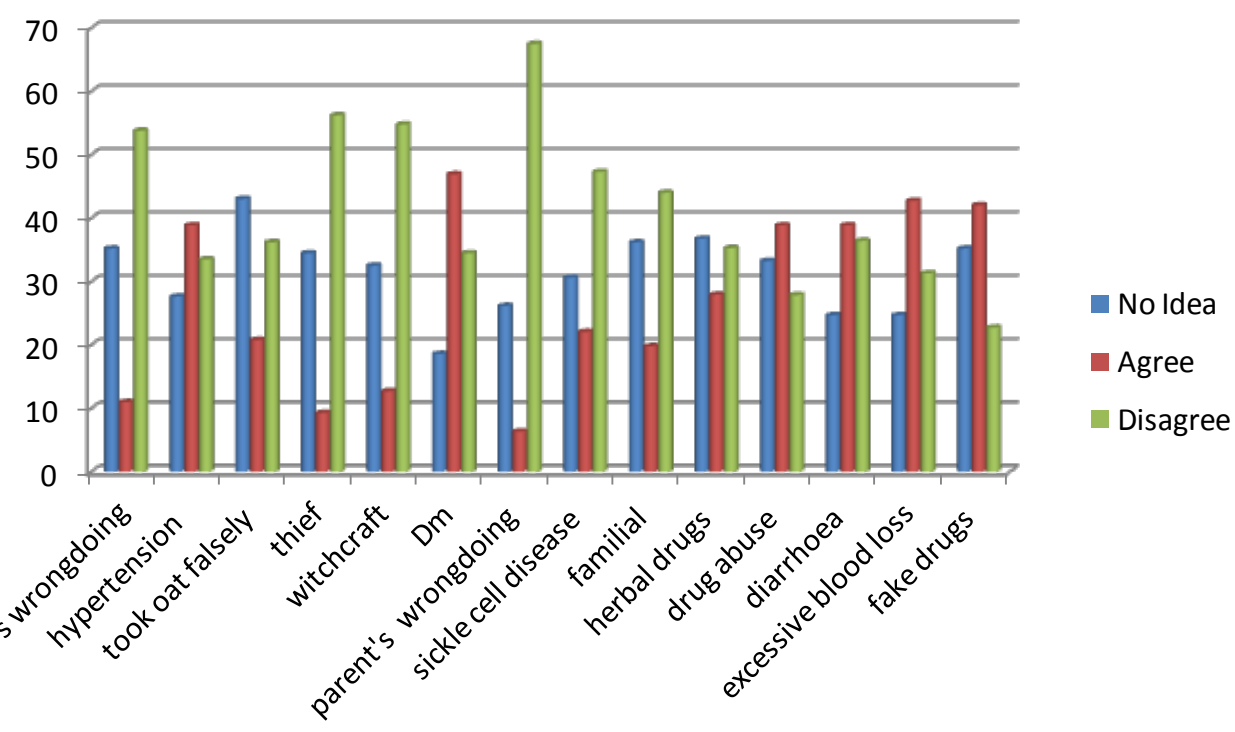

Figure 2. Histogram showing knowledge and perception of causes of kidney failure.

kidneys are located in the abdomen. This was comparable with $44 \%$ reported by Okwuonu et al. [3]. Fifty two percent of respondents, compared with 43.2\% reported by Okwuonu, said the kidneys are located in the chest. This was surprising because we studied the mainly urban population with more educated respondents while theirs was on semi-urban population. The study by Okaka and Ojukwu revealed good knowledge of location of kidney and functions [5]. This may be because their respondents were mainly undergraduates whereas we included both educated and uneducated subjects. However, the knowledge of the number of kidneys by our respondents was very good. Only 2.8\% did not know the total number of kidneys per individual compared with 5\% by Okaka and Ojugwu [5] and $9.9 \%$ by Alebiosu [7]. This may be unconnected with their level of education because there were more people with higher levels of education in Alebiosu's study (68.9\%) compared with $49.8 \%$ in our study (Table 1). Our study was however different from that of Alebiosu because we excluded hospital administrative and support staff who may have little medical knowledge from their day to day contact with patients. This is however surprising considering the fact that $52.2 \%$ said that the kidneys were located in the chest 
except if they wrongly thought that the lungs and the kidneys are synonymous. However, this is difficult to sustain because the meaning of kidney was interpreted to all respondents in vernacular. Respondents had good knowledge of kidney functions except functions relating to blood production. Ninety five percent and $90.4 \%$ agreed that kidney functions in urine formation and excretion of waste from the body respectively. This was higher than that of $65.8 \%$ in Alebiosu's study.

Knowledge of symptoms of kidney failure was fair as $88.3 \%, 76.8 \%, 82.5 \%$ and $75.6 \%$ believed that body swelling, fatigue, reduction in urinary output, and facial swellings are symptoms of kidney failure. This showed an improvement when compared with $23.9 \%, 13.5 \%$ and $0.7 \%$ of body swelling, body weakness and facial swelling respectively, reported by Alebiosu. Okaka and Ojugwu also reported a lower percentage of $61 \%, 68.1 \%$ and $49.2 \%$ corresponding to body swelling, inability to pass urine and fatigue respectively. This showed a marked improvement especially on the knowledge of body swelling which is the commonest symptom of kidney failure [6]. However knowledge of nocturia, lack of blood, vomiting and hiccups are still poor and needs more enlightenment.

Knowledge of the causes of kidney failure was very poor. Eleven percent (11\%) of respondents believed that kidney disease is caused by a patient's wrongdoing. Surprisingly, this belief was common among those with higher levels of education than those with a secondary level of education and below. It was difficult to explain this statistical difference as we expected the reverse. We observed that certain beliefs are still very strong among the studied population. $20.9 \%$ of respondents believed that kidney disease is as a result of having sworn to an oath falsely for an offence the patient had committed while $6.36 \%$ believed that it is because of the parent's wrongdoing. These beliefs were not influenced by level of education as there was no statistically significant difference between those with higher education and those with secondary school education and below. Less number of highly educated respondents compared with those with secondary school education and below did not believe that kidney disease is as a result of thief ( $\mathrm{p} \leq 0.0001)$. Those who attributed kidney failure to witchcraft were $12.7 \%$ (Figure 2). These beliefs may impact negatively on the willingness of the populace in seeking proper medical treatment on time and may be one of the main reasons for their late presentation in the hospitals. These types of belief are well established in patients suffering from epilepsy [8]. More enlightenment needs to be carried out to dissuade our people from these Stone Age beliefs.

Only $38.88 \%$ and $46.94 \%$ of respondents believed that hypertension and diabetes are causes of kidney disease. This is appalling considering the fact that hypertension and diabetes remain the leading causes of chronic kidney disease the world over including Nigeria [9] [10]. Also the prevalence of hypertension is on the increase in our rural and urban communities [11] [12]. However the well educated respondents had better knowledge of both hypertension and diabetes as possible causes than the less educated ( $\mathrm{p}<0.001$ and 0.002 respectively).

Adult polycystic kidney disease and sickle cell disease are known familial causes of kidney disease. However , more than $50 \%$ of respondents did not believe that sickle cell anaemia is a cause of CKD and only $19.8 \%$ believed that CKD could be hereditary [13] [14]. More of the well-educated believed that CKD may be inherited when compared with the less educated respondents $(\mathrm{p}<0.0001)$.

On drugs as a cause of CKD, only about a quarter (27.9\%) of the respondents believed that herbal drugs can be a cause, while less than half believed that drugs abuse and fake drugs can cause kidney disease (Table 3). This is lower than $30.6 \%$ of Okwuonu et al. [3], but slightly higher than Okaka and Ojukwu [5] despite the facts their study population was mainly students. Herbal medications/concoctions are known causes of kidney failure in Nigeria [4] [15]. This is alarming considering the proliferation of herbal medicine vendors in all nooks and crannies of our communities. All efforts must be on deck in disseminating information to the gullible public on the dangers posed by some of these drugs. Knowledge of excessive blood loss and diarrhoea as a cause of kidney failure was also poor.

\section{Conclusion}

Although there is little improvement in the knowledge of the kidney and its diseases, the knowledge of causes of kidney failure is still very poor. There is therefore an urgent need for health practitioners, the media and schools to increase their level of information on kidney disease, causes and prevention to general public.

\section{Limitation}

This study was done among the urban dwellers and there were more educated respondents. Same study need to 
be replicated in the rural communities.

\section{Conflict of Interest}

We declare no conflict of interest.

\section{References}

[1] Murray, C.J.I., Ezzati, M., Flaxman, A.D., et al. (2012) GBD 2010: Design, Definition and Metrics. Lancet, 380, 2063-2066. http://dx.doi.org/10.1016/S0140-6736(12)61899-6

[2] Ijoma, C.K., Ulasi, I.I. and Kalu, A.O. (1998) Cost Implications of Treatment of End Stage Renal Disease in Nigeria. Nigerian Journal of College of Medicine, 3, 95-96.

[3] Okwuonu, C.G., Chukwuonye, I.I., Ogah, S.O., Abali, C., Adejumo, O.A. and Oviasu, E. (2015) Awareness of Level of Kidney Functions and Disease among Adult in a Nigerian Population. Indian Journal of Nephrology, 25, 158-163. http://dx.doi.org/10.4103/0971-4065.139096

[4] Kadiri, S., Arije, A. and Salako, B.L. (1999) Traditional Herbal Preparations and Acute Renal Failure in South West Nigeria. Tropical Doctor, 22, 224-226.

[5] Okaka, E.L. and Ojogwu, L.I. (2012) Aweareness Level of Kidney Disease among Non-Medical Students in Benin City, Nigeria. JMBR, 11, 29-34.

[6] Arogundade, F.A., Sanusi, A.A., Hassan, M.O. and Akinsola, A. (2011) The Pattern, Clinical Characteristics and Outcome of ESRD in Ile-Ife, Nigeria: Is There a Change in Trend? African Health Sciences, 11, 594-601.

[7] Alebiosu, C.O. (2002) Awareness of Kidney Disorders in Nigeria. African Journal of Health Sciences, 9, 165-168.

[8] Sanya, E.O., Salami, T.A.T., Goodman, O.O., Buhari, O.I.N. and Araoye, M.O. (2005) Perception and Attitude to Epilepsy among Teachers in Primary, Secondary and Tertiary Educational Institutions in Middle Belt Nigeria. Tropical Doctor, 35, 153-156. http://dx.doi.org/10.1258/0049475054620905

[9] Alebiosu, C.O., Ayodele, O.O., Abbas, A. and Olutoyin, I.A. (2006) Chronic Renal Failure at Olabisi Onabanjo University Teaching Hospital, Sagamu, Nigeria. African Journal of Health Sciences, 6, 132-138.

[10] US Renal Data System (2011) USRDS 2011 Annual Data Report: Atlas of Chronic Kidney Disease and End-Stage Renal Disease in the United States. National Institutes of Health, National Institute of Diabetes and Digestive and Kidney Disease. Bethesda.

[11] Ulasi, I.I., Ijoma, C.K., Onwubere, B.J.C., Arodiwe, E., Onodugo, O. and Okafor, C. (2011) High Prevalence and Low Awareness of Hypertension in a Market Population in Enugu, Nigeria. International Journal of Hypertension, 2011, Article ID: 869675.

[12] Akpan, E.E., Ekrikpo, U.E., Udo, A.I.A. and Bassey, B.E. (2015) Prevalence of Hypertension in Akwa Ibom State South-South Nigeria: Rural versus Urban Communities Study. International Journal of Hypertension, 2015, Article ID: 975819. http://dx.doi.org/10.1155/2015/975819

[13] Dana, V.R. and Arlene, B.C. (2014) Polycystic and Other Cystic Kidney Disease. In: Scott, J.G., Daniel, E.W., Debbie, S.G., Mark, A.P., Marcello, T., Eds., Primer of Nephrology, 6th Edition, Elsevier Saunders, Philadelphia, 362-370.

[14] Vimal, K.D. (2014) Sickle Cell Nephropathy. In: Scott, J.G., Daniel, E.W., Debbie, S.G., Mark, A.P. and Marcello, T., Eds., Primer of Nephrology, 6th Edition, Elsevier Saunders, Philadelphia, 357-361.

[15] Akpan, E.E. and Ekrikpo, U.E. (2015) Acute Renal Failure Induced by Chiene Herbal Medication in Nigeria. Case Reports in Medicine, 2015, Article ID: 150204. 